University of Nebraska - Lincoln

DigitalCommons@University of Nebraska - Lincoln

2004

\title{
New Species of Cerambycidae (Coleoptera) from Puerto Rico with Records and Notes for Other Species
}

Steven W. Lingafelter

Systematic Entomology Laboratory, ARS, USDA, National Museum of Natural History, MRC-168,

Washington, DC 20560

Charyn J. Micheli

Department of Entomology, University of Maryland, College Park, Maryland 20742

Follow this and additional works at: https://digitalcommons.unl.edu/systentomologyusda

Part of the Entomology Commons

Lingafelter, Steven W. and Micheli, Charyn J., "New Species of Cerambycidae (Coleoptera) from Puerto Rico with Records and Notes for Other Species" (2004). USDA Systematic Entomology Laboratory. 28. https://digitalcommons.unl.edu/systentomologyusda/28

This Article is brought to you for free and open access by the Entomology Collections, Miscellaneous at DigitalCommons@University of Nebraska - Lincoln. It has been accepted for inclusion in USDA Systematic Entomology Laboratory by an authorized administrator of DigitalCommons@University of Nebraska - Lincoln. 


\title{
NEW SPECIES OF CERAMBYCIDAE (COLEOPTERA) FROM PUERTO RICO WITH RECORDS AND NOTES FOR OTHER SPECIES
}

\author{
Steven W. Lingafelter ${ }^{1}$ And Charyn J. Micheli ${ }^{2}$ \\ ${ }^{1}$ Systematic Entomology Laboratory, ARS, USDA, \\ National Museum of Natural History, MRC-168, \\ Washington, DC 20560; and \\ ${ }^{2}$ Department of Entomology, University of Maryland, \\ College Park, Maryland 20742
}

\begin{abstract}
An intensive survey for Cerambycidae of El Yunque National Forest and many of the state forests in Puerto Rico showed 49 species representing over half of the hitherto reported species from the Island. Two tribes and four genera are recorded from Puerto Rico for the first time. The description of a new genus, Pseudothonalmus Guerrero, is included. Four new species are described: Elateropsis julio Lingafelter and Micheli, Pseudothonalmus woodleyi Lingafelter, Micheli, and Guerrero, Styloleptus taino Lingafelter and Micheli, and Distenia puertoricensis Lingafelter and Micheli. The larva of Parandra tavakiliani is described. Locality data and method of collection are provided for all encountered Cerambycidae.
\end{abstract}

Resumen.-Una expedición para colectar Cerambycidae en el Bosque Nacional El Yunque y varios otros bosques estatales de Puerto Rico encontró 49 especies lo cual representan más de la mitad de las especies reportadas para la Isla. Dos tribus y cuatro géneros son reportados por primera vez para Puerto Rico. Se describen un nuevo género, Pseudothonalmus Guerrero, y cuatro especies: Elateropsis julio Lingafelter and Micheli, Pseudothonalmus woodleyi Lingafelter, Micheli, and Guerrero, Styloleptus taino Lingafelter and Micheli y Distenia puertoricensis Lingafelter and Micheli. La larva de Parandra tavakiliani se describe. Datos de localidad y método de colección se proveen para todos los Cerambycidae encontrados.

There have been few studies of Puerto Rican longhorned woodboring beetles and never an intensive survey throughout the island specifically for Cerambycidae. Several general faunal lists that include the cerambycids of Puerto Rico have been published, including Stahl (1882), Gundlach (1894), Wolcott (1924, 1936, 1948), Blackwelder (1946), and Ramos (1946). Warren Fisher was the most prolific describer of cerambycids from Puerto Rico (and elsewhere in the Caribbean), publishing numerous papers from the 1920's through 1940's (Fisher, 1925, 1926, $1932,1935,1942,1947)$. Other researchers who have described or treated the cerambycid fauna of Puerto Rico include Leng and Mutchler (1914), Dillon and Dillon (1946), Gilmour (1963), Tyson (1973), J. Micheli (1978, 2003 with Hovore), Chemsak (1979), and Ivie (1985, in prep. with Schwengel-Regala). Other important references relating to Caribbean cerambycid taxa include Zayas $(1957,1975)$ and Cazier and Lacey (1952).

Two expeditions were made by the authors to Puerto Rico in June-July, 2002, and June, 2003. Although much of the island has lost its virgin habitat due to agriculture and development, there are many state forests as well as a national forest (El Yunque) that are protected and contain relatively rich fauna and flora. We maximized coverage of ecological zones and chose 12 forests (Fig. 1) in which to survey for Cerambycidae. These include (with 


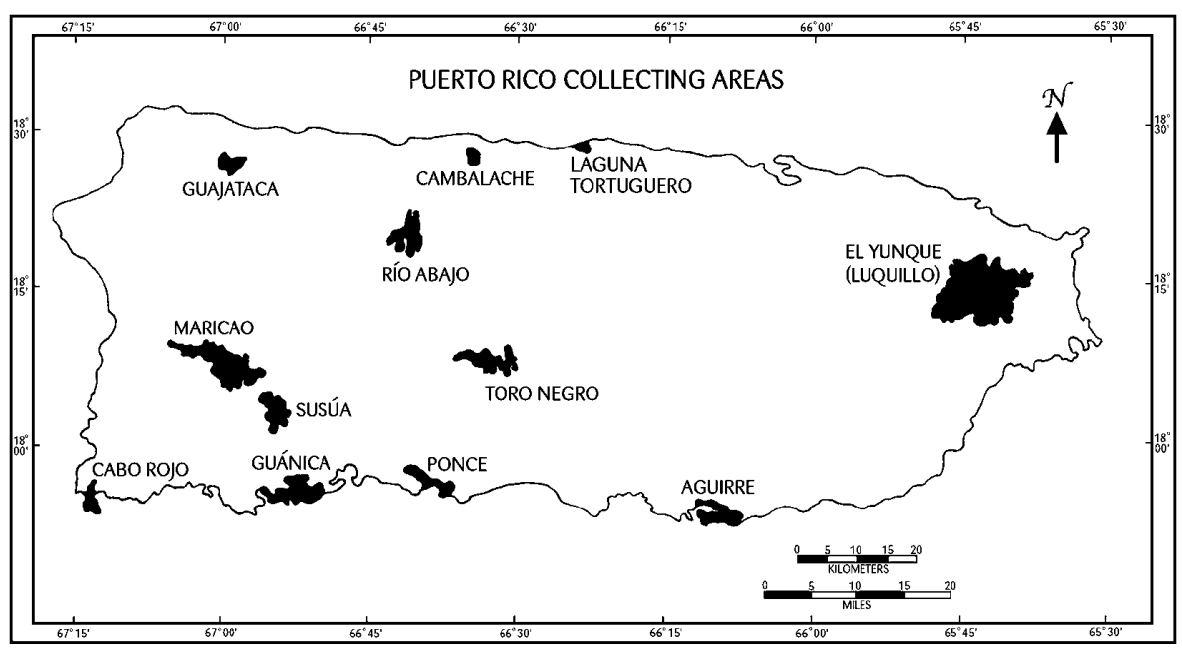

Fig. 1. Map of Puerto Rico showing collecting localities.

ecological descriptions of L. R. Holdridge from a map prepared by Ewel and Whitmore, 1973): Cambalache, Guajataca, Laguna Tortuguero, and Susúa (subtropical moist forests), Río Abajo and Maricao (subtropical and lower montane wet forests), Toro Negro (lower montane wet forest), Cabo Rojo, Guánica, Ponce, and Aguirre (subtropical dry forests), and El Yunque Caribbean National Forest (subtropical lower montane rainforest). Collecting methods included beating of vegetation, examination of lights at night, and sugar-bait trapping.

The following acronyms are used throughout the paper: National Museum of Natural History, Washington, DC (USNM); Julio and Charyn Micheli private collection, Ponce, PR (JAMC); West Indian Beetle Fauna Project, Michael Ivie, Montana State University, Bozeman, MT (WIBF); Roy Morris private collection, Lakeland, FL (RMPC); Robert Turnbow private collection, Ft. Rucker, AL (RTPC); and Dan Heffern private collection (DHPC).

\section{RESULTS}

Forty-nine species of Cerambycidae were collected (Table 1) which together represent over half of the previously recorded species from Puerto Rico. We report the first records for Puerto Rico of two tribes (Heteropsini and Callichromatini) and four genera (Elateropsis, Plinthocoelium, Styloleptus, and Pseudothonalmus, new genus). Four new species were discovered and descriptions of them and the larva of Parandra tavakiliani are presented. These new species are: Elateropsis julio Lingafelter and Micheli (Prioninae: Solenopterini), Pseudothonalmus woodleyi Lingafelter, Micheli, and Guerrero (Cerambycinae: Heteropsini), Styloleptus taino Lingafelter and Micheli (Lamiinae: Acanthocinini), and Distenia puertoricensis Lingafelter and Micheli (Disteniinae: Disteniini). A complete list of the 49 species encountered (arranged alphabetically within each subfamily) and their localities and methods 


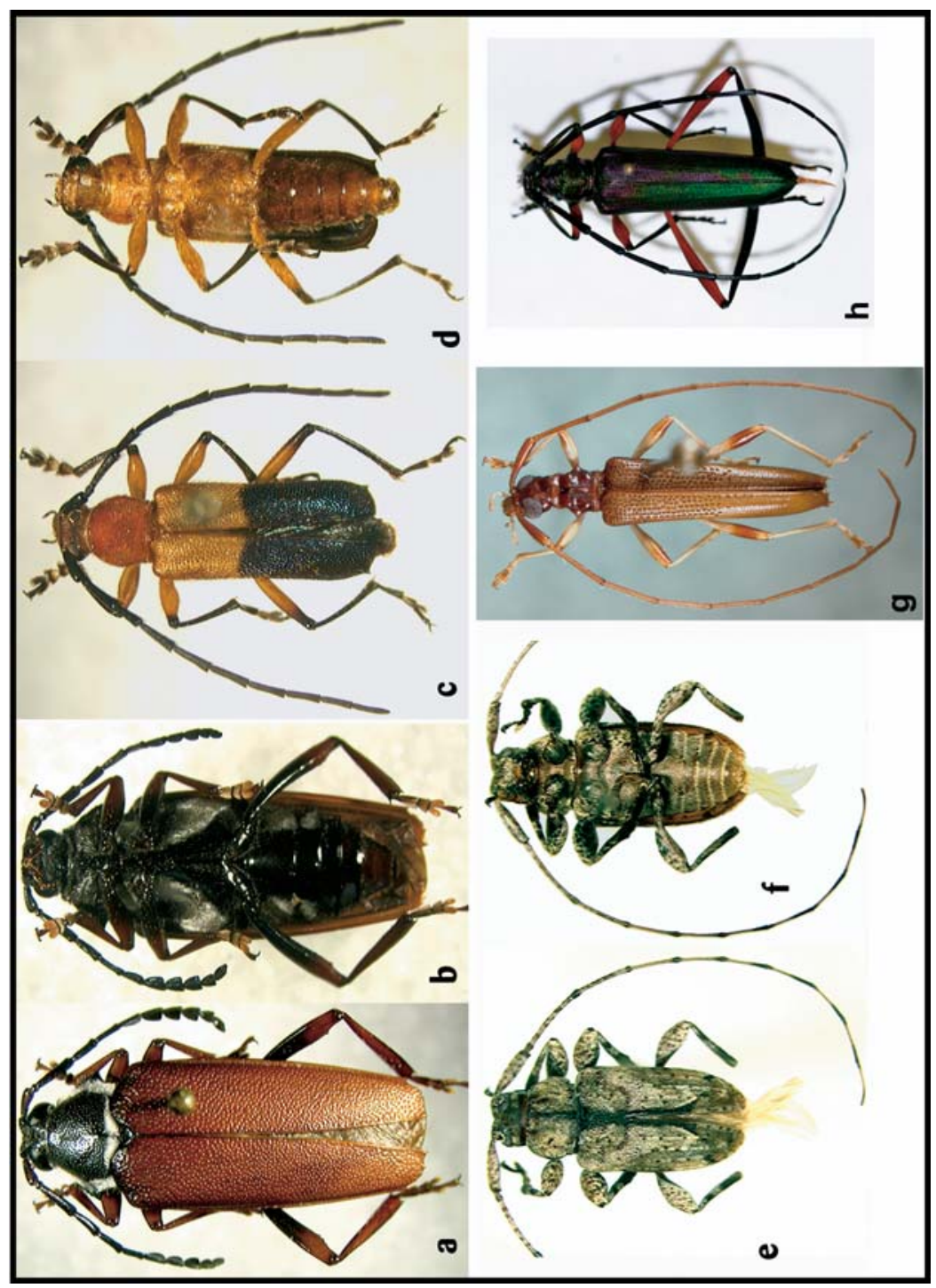

पँ

苍苍离

응 跑

फ

3.

$\frac{0}{7}$ छ

预

$\frac{0}{2} \div$

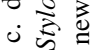

उั

.

중 훙

苞定

$>$

速造

ค 要

is 웅

.0

$\ddot{\ddot{z}}$

क

咅

$\rightarrow=\frac{0}{2}$

过

感

च्चे पै

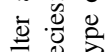

के क्षात

.0

:

:월

ڤ气

के 흥

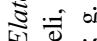

苍焉

0

응 或

年

पै

उ

$\stackrel{2}{\approx}$

च $\ddot{\mathrm{s}}$ ज

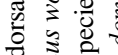

- 5 咅

i

요

品 


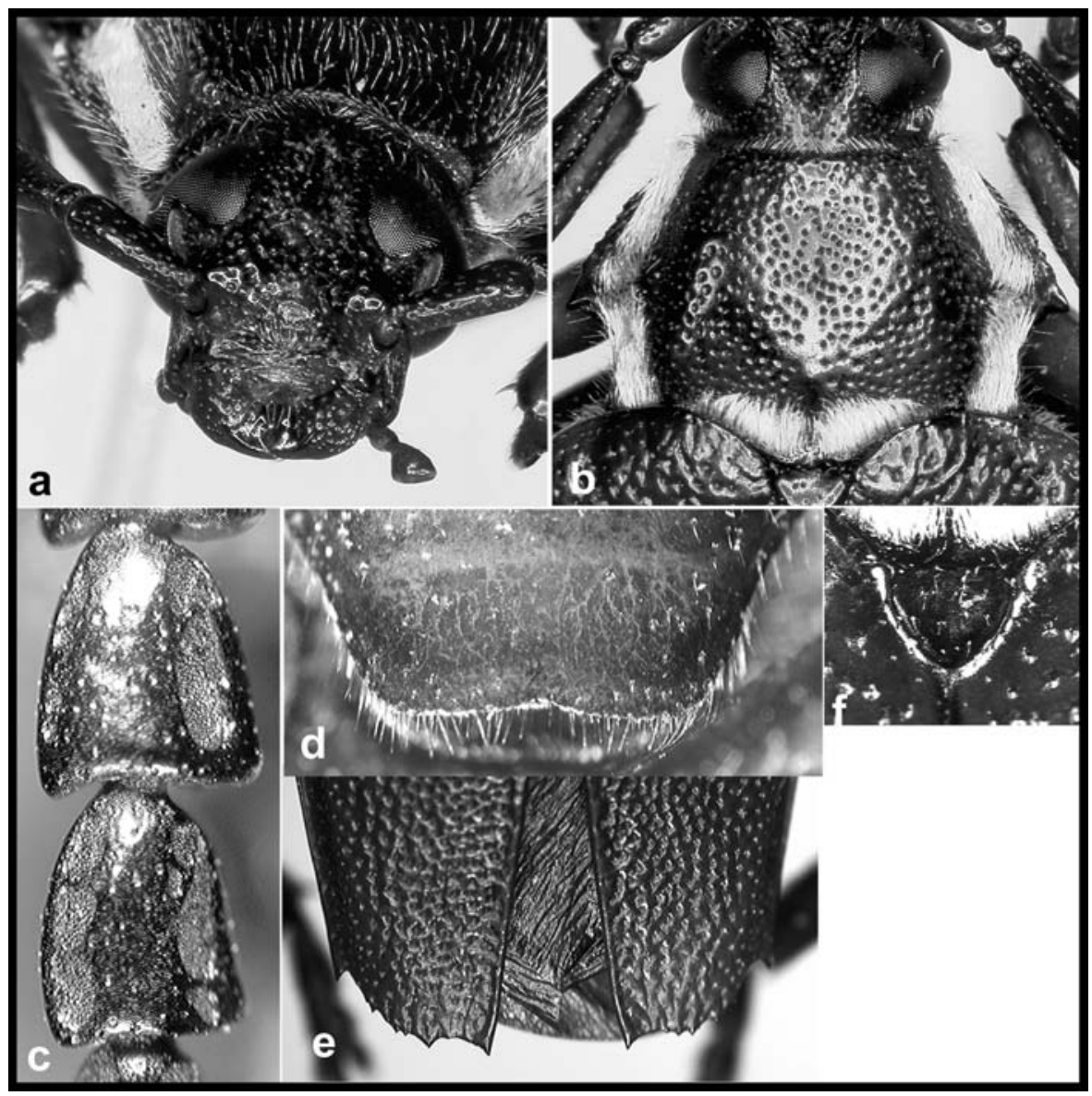

Fig. 3. Characters of Elateropsis julio Lingafelter and Micheli, new species: a. anterior view of head; b. dorsal view of pronotum and head vertex; c. closeup of sensory poriferous regions of antennomeres 89; d. last ventrite of female; e. apex of elytra; f. scutellum.

of collection follows the species descriptions. This information is provided to be available for a book on Cerambycidae of Puerto Rico that is being prepared by Julio Micheli.

Elateropsis julio Lingafelter \& Micheli, new species

Figs. 2a, b; 3a-f

Description (based on unique female specimen). Medium, $17.5 \mathrm{~mm}$ long; integument mostly black, except for elytra, legs beyond basal one-half of femur, palpi, and ventrites which are ferrugineous. Head (Fig. 3a) with v-shaped interantennal and vertex notch; finely punctate; with sparse pale hairs, most numerous along posterior eye margin. Antennal tubercles not 
pronounced. Antennae glabrous, reaching middle of elytron. Antennomeres flattened, poriferous sensory areas present mesad (Fig. 3c) and laterad on all antennomeres but not on central portions. Poriferous areas oval in shape, not striolate. Last antennomere 1.25 times length of penultimate antennomere. Antennomeres gradually decreasing in length to antennomere 10, antennomeres 9-11 noticeably narrower than 6-8. Pronotum (Fig. 3b) about 1.3 times as wide as long, surface without raised calli or indentations; rather flat on disk. A poorly delineated longitudinal line present at posterior middle. Pronotum broadly rounded and widened at sides; a blunt, posteriorly directed projection at margin just posterior to middle, then an arcuate indentation to posterolateral margin. Pronotum not conspicuously pubescent except at lateral and posterior margins where a dense, white coating of hairs is present. Otherwise sparse, inconspicuous, translucent hairs present on disk. Pronotal disk with numerous, shallow punctures, but these not confluent and mostly spaced from their neighbors by at least their radius. Apex of prosternal process strongly notched around mesosternum; sparsely pubescent and punctate. Elytra glabrous, gradually narrowing apically; divergent at suture (particularly at apical one-third). Punctation dense, in part confluent, but punctures not deep and surface not reticulate, rough or uneven. Elytral apex (Fig. 3e) rounded and unevenly dentate with seven denticles. Scutellum (Fig. 3f) shaped as a broad, equilateral triangle, posterior not narrowed and elongate; mostly smooth without punctation or pubescence. Legs short, hind femur extending to about apical one-third of elytron. Metafemur with 2-3 denticles ventrally between middle and apex. Venter (Fig. 2b) mostly glabrous or indistinctly pubescent with translucent hairs except for mesepisternum, metepisternum (primarily posterior one-third), most of metasternum, and first and second ventrites which have dense, white pubescence as on margins of pronotum. Last ventrite of female (Fig. 3d) with small medial notch.

Discussion. Based on the divergent elytral apices and lack of a sulcus or impression on the pronotum, this species is most similar to the variable Elateropsis fulvipes (Chevrolat) and would key near that species in Galileo and Martins (1994). Most commonly black with dense, white pubescence on the lateral and posterior margins of the pronotum and on each elytron, E. fulvipes can vary by having only the head and pronotum black while having the legs, antennae and elytra entirely ferrugineous, or by being entirely black, without any dense, white pubescence dorsally. The new species, E. julio, differs in having uniformly ferrugineous elytra, bicolored legs (black at basal one half, ferrugineous in remainder), black head, pronotum, antennae, and venter, and elytron without dense, white pubescence. Elateropsis julio has a distinctively short, equilateral triangle shaped scutellum that is mostly smooth, without punctation. Only E. fellerae (Chemsak), which is superficially similar to $E$. julio in the coloration of body and appendages, has a similarly shaped scutellum. Comparing the holotype of $E$. fellerae with the holotype of $E$. julio (both female), E. fellerae differs in having the scutellum obviously punctate, in having deeper punctures on the elytron, and in having many more poriferous areas on the antennae, including the center of the terminal four antennomeres (in E. julio, the antennal poriferous areas are restricted to oval regions on the mesal and laterad areas of each antennomere).

The single known specimen was collected during day after it alighted on a small Croton sp. $(<2 \mathrm{~m}$ tall $)$ that was covered by a leafy vine. This species is quite rare and consequent attempts to collect more specimens have proven fruitless.

Etymology. This species epithet is a noun in apposition named for Julio Micheli with our admiration for his contributions to art and coleopterology.

Types. Holotype, female, PUERTO RICO, Municipio de Ponce, Tuque, elevation 70-80 m, $17^{\circ} 58^{\prime} 42^{\prime \prime} \mathrm{N}, 66^{\circ} 40^{\prime} 21^{\prime \prime} \mathrm{W}, 20$ June 2002, S. W. Lingafelter \& N. E. Woodley (USNM). 


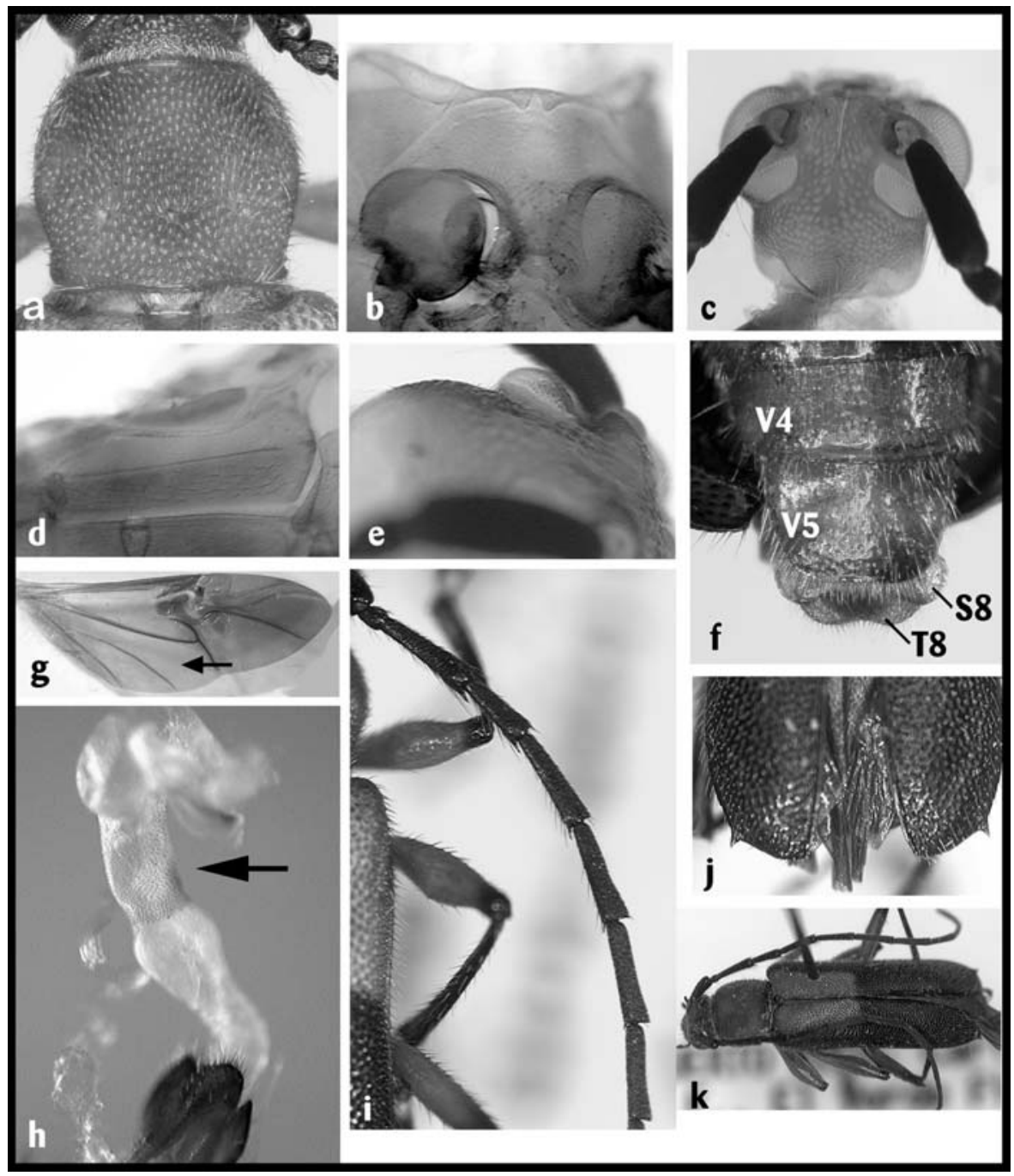

Fig. 4. Characters of Pseudothonalmus Guerrero, new genus, and P. woodleyi Lingafelter, Micheli, and Guerrero, new species: a. dorsal view of pronotum; b. cleared mesosternum; c. cleared head; d. cleared metepisternum; e. lateral view of cleared antennal tubercle and upper eye lobe; f. abdominal apex of male, showing ventrites 4-5, sternite 8 , and tergite 8 ; g. hind wing (note absence of veins in region at arrow); h. extruded internal sac (note microspicules at arrow); i. closeup of antennae showing mesal spines on 3-7; j. apex of elytra; k. paratype of $P$. woodleyi showing variant elytral maculation (RTPC). 
Pseudothonalmus Guerrero, new genus

Figs. 2c, d; $4 \mathrm{a}-\mathrm{k}$

Type species. Pseudothonalmus woodleyi Lingafelter, Micheli, and Guerrero, new species. Other included species. Pseudothonalmus divisus (Chevrolat, 1858: 210), new combination (formerly Trichrous)

\section{Pseudothonalmus terminalis (White, 1853: 123), new combination (formerly Trichrous) Pseudothonalmus major (Gahan, 1895: 117), new combination (formerly Trichrous)}

Diagnosis. The variably costate elytra, coarse punctation on head, pronotum, and elytra, curved, acute, offset apicolateral spine of the elytron, deeply sinuate epipleural margin, relatively long third antennomere, mesal antennal spines, coarsely-faceted eyes, erect elytral setae and absence of elytral eburneous calli distinguish this genus.

Description. Small, 7.5-9.0 mm. Head frons, vertex, occiput coarsely, confluently punctured, becoming denser at posterior margin. Impunctate region on vertex between upper eye lobes very narrow (Fig. 4c). Antenna 11-segmented. Antennal tubercles short, not extending above plane of upper eye lobe (Fig. 4e). Mesal spines on antennomeres 3-6 or 7 (7th spine may be minute) (Fig. 4i) (females unknown, may differ). Antennomeres subequal in length except fourth antennomere which is distinctly shortest of all and last antennomere which is approximately 1.25 times length of others. Antennomeres slightly flattened and produced apicolaterally. Eye large, protruding from sides of head (Fig. 4c). Ratio of width of head between eyes at widest point versus width at postoccipital region (behind upper eye lobes) is 1.4. Lower eye lobes extending anteriorly to plane of frontoclypeal margin. Eyes finely faceted, with upper eye lobes of 8-9 rows of facets. Labium with palpus 4-segmented (basal-most segment indistinct). Maxilla with palpus 5-segmented (first palpomere [palpifer] minute and barely protruding above plane of lacineal base). Well-defined digitiform sensillum patch on outer (lateral) region of apical palpomere extending from just distal to base to apical one-third. Mandible broadly triangular, cutting surface weakly excavated with one or two teeth. Gula approximately one-fourth to one-fifth width of head at occipital region. Pronotum (Fig. 4a) coarsely and confluently punctured, each puncture bearing a single, short seta. No calli, lateral swellings, or spines present. Prosternal intercoxal process about one-fourth width of procoxa; apex weakly expanded. Each coxa open posteriorly by approximate width of procoxal process. Mesonotum with lateral margin containing patches of regularly distributed setae and a medial, rounded articulation. Stridulatory region of mesonotum ill-defined, striae not visible. Scutellum triangular, elongate, narrowly rounded posteriorly; very sparsely pubescent; distinctly delineated from remainder of mesonotum; weakly constricted anteriorly. Mesepimeron not contacting mesocoxa, therefore mesocoxal cavities closed laterally by contact of mesosternum and metepisternum. Mesepisternum with distinct carina on dorsal and anterior margin. Mesosternum (Fig. 4b) with anterior margin delineated with narrow, arcuate, pigmented sclerotization with narrow, acute, $\mathrm{V}$-shaped indentation at middle. Mesosternal intercoxal process slightly narrower than coxa; without lateral projection into coxa. Metasternum densely pubescent (Fig. 2d), finely punctate with subacute notch for reception of first ventrite process; broadly articulating with mesosternal process. Metasternal notch attaining apex of metatrochanter plane. Metepisternum (Fig. 4d) with distinct transverse carina with stronger sclerotization on ventral half. Elytron densely, completely covered with mostly uniform-sized punctures; costae weak to moderate. Apex with outer apical spine present, otherwise rounded to 
suture (Fig. 4j). elytral pubescence uniformly distributed, but varies in density and color (translucent, amber, or black) among species. Hind wing with derived venation typical for Trachyderoinea, MP4+CuA1+2 absent (Fig. 4g). Legs with profemur and mesofemur weakly enlarged near middle; metafemur linear. Apices around tibial insertion acute, but not spinose or dentiform. Tibiae linear, without carinae. Two well-developed spurs apically on all tibiae. Tarsal claws simple, divaricate. Fifth tarsomere about twice as long as third on all legs. Abdomen with apex of male terminal ventrite broadly rounded, without depression or indentation at apex (Fig. 4f). Male genitalia (based on $P$. woodleyi) with median lobe weakly curved; parameres short, with apices densely setose and narrowly separated. Internal sac transparent, membranous, with band of microspicules at middle extending one-fifth of overall length (Fig. 4h). Eighth sternite deeply cleft and much broader at apex than apex of last ventrite or tergite 8 (Fig. 4f). Female genitalia (females unknown).

Etymology. Based on the superficial similarity of the included species to members of the genus Thonalmus Bourgeois (Lycidae).

Discussion. Kelvin Guerrero is working on other papers involving the description and transfer of various species of West Indian Heteropsini (Guerrero, 2001, in prep. [with M. Ivie]). He has kindly consulted with us regarding the following new species and written the description of Pseudothonalmus, new genus, for inclusion in our paper and into which he recommends placement of the new species and three others formerly included in Trichrous. This genus belongs in the Heteropsini, but the presence of the ventral metepisternal sclerotization combined with mesal antennal spines and lack of eburneous calli on the elytra are characters not present in Heterops and justify proposing a new genus.

\section{Pseudothonalmus woodleyi Lingafelter, Micheli, \& Guerrero, new species}

Figs. 2c, d; 4a-k

Description. Small, 7.5-9.0 mm long; integument variably colored from pale orange to piceous in regions. Head mostly pale orange to partially piceous; glabrous and coarsely, densely punctate. Interantennal impression weak; antennal tubercles not pronounced. Antennae piceous, coated with short, translucent to amber pubescence; surpassing elytron by about 1-2 antennomeres. Antennomere four noticeably shorter than adjacent antennomeres. Antennomeres 3-7 having apical-mesad spines (Fig. 4i). Pronotum (Fig. 4a) darker orange than surrounding integument; some specimens with black at sides; about as wide as long, weakly, broadly rounded at sides, with inconspicuous, pale, suberect hairs, more abundant at sides. Pronotum completely punctate, somewhat intermediate condition of alveolate and areolate pattern. Scutellum pale orange to dark, narrowly rounded posteriorly and with very inconspicuous, translucent pubescence. Venter punctation of prothorax sparse. Prosternal process between procoxae about one-half width of procoxa; apex weakly expanded, procoxa open posteriorly by about one-half width of apex of prosternal process. Venter of mesothorax, metathorax, and abdomen variably colored from pale orange to piceous. Elytron mostly parallel-sided but slightly constricted at middle. Posterior one-half or more dark, weakly iridescent purple; purple macula extending on side to anterior margin in one specimen (Fig. 4k); otherwise orange. Pubescence translucent, regularly, densely distributed and erect (but short), though weakly posteriorly directed. Punctation coarse, confluent, regularly distributed. Base of elytron sinuate with parascutellar area and humeral area raised and a lower channel present between them extending posteriorly about one-third length of elytron. Outer 
elytral apex with small spine and apex as in Fig. 4j. Legs moderate in length, hind femur extending to about apex of elytron. Tibiae dark brown to black; apex of femora dark brown to black; most tarsomeres bicolored with at least apical one-half dark brown to black and basal half pale orange. Genitalia (see generic description).

Discussion. This species is very similar to Pseudothonalmus divisus (Chevrolat) in overall coloration, the apically spined elytron, and the punctation of the pronotum. It differs in having nearly the entire femur pale except for the apex (all black except the base in $P$. divisus) and in having the pubescence of the body denser, shorter, and translucent or amber colored (sparser, longer, and black, or a mixture of black and translucent in $P$. divisus).

Etymology. This species epithet is a genitive latinized noun named for our good friend and colleague, Norman Woodley, who collected the holotype. Kelvin Guerrero, the third author of this species, independently discovered the second known specimen in the USNM collection and the joint authorship reflects this mutual discovery.

Types. Holotype, male, PUERTO RICO, Maricao State Forest, Road 120 at km 13.2 (across from rec. cabins), $18^{\circ} 09^{\prime} 52^{\prime \prime} \mathrm{N}, 66^{\circ} 54^{\prime} 14^{\prime \prime} \mathrm{W}, 800 \mathrm{~m}, 14$ June 2002 , N. E. Woodley (USNM). Collected in daytime flight. Paratypes: 1 male, PUERTO RICO, Mayagüez, 10 April 1955, P. Rodríguez, coll., at light (USNM, specimen disarticulated and preserved in alcohol); 1 male, PUERTO RICO, Caribbean National Forest, El Verde Field Station, 26 May 1994, Robert Turnbow (RTPC).

Styloleptus taino Lingafelter \& Micheli, new species

Fig. 2e, $\mathrm{f}$

Description (based on unique male specimen). Small, $7 \mathrm{~mm}$ long; integument mostly shining, reddish brown, except tarsi, gena, postgena, and areas of the femora, which are dark brown; pubescence dense, short, recumbent, off-white to pale brown, with black spots and a longitudinal median black line from anterior of pronotum to apical third of elytra. Head with a deep v-shaped depression between the antennal tubercles, which are developed and divergent; impunctate; pubescence short, dense, appressed, off-white and pale brown giving a mottled appearance. Front subquadrate, almost flat, with a narrow, median line from epistoma to occiput. Eyes deeply emarginate, with upper eye lobes separated from each other by 1.5 times width of lobe. Antenna of male almost twice length of body (Fig. 2e, f). Antennomeres subcylindrical; gradually decreasing in length to segment 6; 6-11 subequal in length. Scape moderately robust, flattened ventrally at base, shorter than antennomere 3 , subequal to 4 . Antennomeres annulated with dark brown at base and apex, the width of annulations increasing apically, and with off-white pubescence, the first four mottled with dark brown. Pronotum about 1.5 times as wide than long, broadest at posterior third, without any distinct tubercles on disk; with sides inflated into a very broad tubercle which is constricted posteriorly. Pronotal disk finely punctate, with row of coarser punctation at posterior and anterior transverse indentations. Pronotum with dense, recumbent, off-white and pale brown pubescence, with distinct median black longitudinal line and two inconspicuous maculae beside it. Pronotal lateral inflation with two black setae on base of each tubercle. Elytra slightly less than 1.5 times as long than wide, slightly broader than pronotum and 3.5 times as long as pronotum. Sides nearly parallel, then arcuately convergent, with suture apically separated; apex of elytron obliquely subtruncate. Punctation, where visible, coarse, punctures approximately separated by width of one puncture. Elytral surface uneven, with several costae, basal tubercles weakly developed. Elytra with offwhite, dense, appressed pubescence, with apical third a darker hue and anterior half of epipleura 
even darker; with black points along costae and black sutural stripe extending to apical third, then obliquely, interruptedly, reaching lateral margin at apical fifth. Scutellum small, nearly twice as broad as long, with rounded apex and covered with black, dense pubescence. Legs short, successively longer posteriorly. Femora robust, clavate, pedunculate, arcuate in middle and hind pair; metafemur not attaining fifth sternite. Integument reddish brown with some dark areas; pubescence mottled with off-white and brown. Tibiae slender, subcylindrical, with two dark incomplete bands laterad, one at middle and one at apex, the latter one much broader. Venter with recumbent, moderately dense, off-white pubescence; impunctate. Prosternal process 0.4 times as wide as procoxal cavity; mesosternal process about as wide as mesocoxal cavity. Fifth abdominal sternite in male broadly truncate, slightly longer than 4th and with a broad, shallow, middle indentation.

Discussion. This species differs from others in the genus in having a median black stripe in its dorsal pubescent pattern and in having the sides of the elytra parallel to the apical fifth. Comparing the type species, Styloleptus biustus (LeConte), with S. taino, S. biustus also differs in the narrower prosternal process ( 0.3 times width of procoxal cavity), in the larger distance between the upper eye lobes, and in having antennomeres 1-6 mottled (1-4 in $S$. taino). Some specimens of $S$. infuscatus (Fisher) and S. variabilis (Fisher) may have a sutural stripe, but in both it is less distinct and their pronota have acute lateral tubercles.

Etymology. This species epithet is a noun in apposition named for the native inhabitants of Puerto Rico, the Taino Indians.

Types. Holotype, male, PUERTO RICO, Aguirre State Forest off Rd. 7710, $17^{\circ} 59^{\prime} \mathrm{N}$, $65^{\circ} 09^{\prime} \mathrm{W}, 2$ July 2002, Steven W. Lingafelter (USNM).

\section{Distenia puertoricensis Lingafelter \& Micheli, new species}

Figs. 2g, 5a, b

Description. Moderate size, 9-12 mm long; width at humeri $2.0-2.5 \mathrm{~mm}$; integument pale orange to light reddish brown; head, pronotum, antennae, apical half of femora, third tarsomeres, most of venter slightly darker; remainder somewhat paler; shining and mostly glabrous; base of elytra and margins of pronotum with a few long translucent hairs, best viewed from lateral perspective. Head with antennal tubercles weakly protruding and connected at middle of head in evenly concave ridge. Head mostly impunctate and glabrous with exception of a few fine punctures at extreme post-occiput and a few long hairs between upper eye lobes; head moderately constricted at region posterior to eye. Eyes large, coarsely faceted, with weak indentation around antennal insertion; eye lobe extends from the vertex to nearly the ventral margin of head when viewed laterally. Upper eye lobes separated by distance greater than middle pronotal callus width. Antenna of male (female unknown) slender, scape at apex is twice as wide as base, remaining antennomeres cylindrical, not enlarged apically; antennomeres 4-7 subequal in length; antennomeres 8-11 slightly shorter but subequal to one another, antennomere 11 not modified; antennomere 3 the longest and slightly longer than scape; antennomere 2 short, approximately as wide as long. Antennae covered with very fine, short translucent pubescence, slightly longer towards apex of antennomeres. Pronotum (Fig. 5b) with large middle callus surrounded by four peripheral calli and with two large lateral tubercles. Constrictions before anterior and posterior margins. The punctures are simple, mostly separate, not rugose around the middle callus and between the middle callus and the four peripheral discal calli; the lateral pronotal tubercle is broad at base 

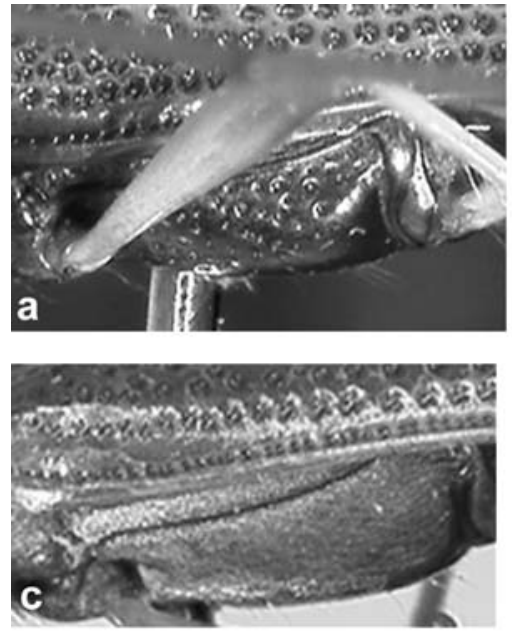
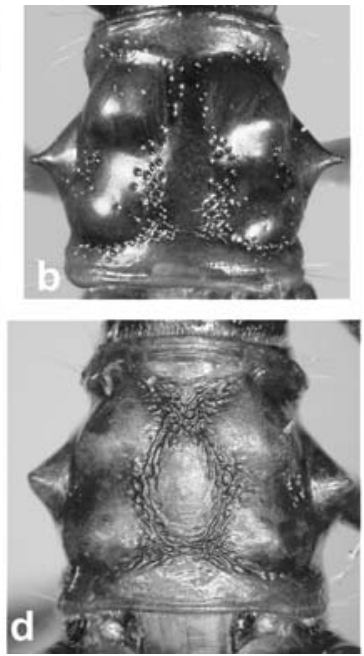

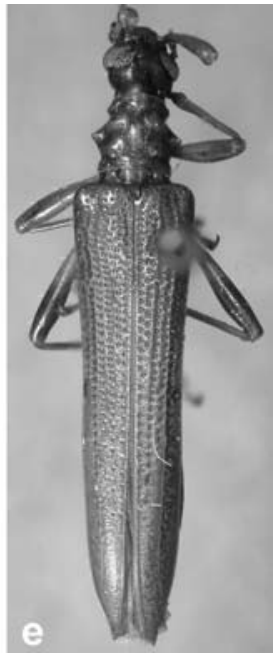

Fig. 5. Characters of Distenia puertoricensis Lingafelter and Micheli and D. darlingtoni Fisher. D. puertoricensis: a. lateral view of metasternum; b. pronotum. D. darlingtoni: c. lateral view of metasternum; d. pronotum; e. D. darlingtoni, paratype.

but greatly constricted at apex into a narrow nipple-like projection. Pronotum glabrous except for a few long translucent setae at anterior and posterior margins. Elytra at base much broader than pronotum; coarsely, deeply punctate, mostly in rows continuing to just beyond middle and abruptly terminating; elytra beyond that point to apex without punctures. Apex bispinose with outer spine strong and sutural spine weaker, rarely dentiform. Elytra gradually narrowed to apex without constriction at middle. Elytra glabrous except for a few long, translucent hairs at base. Scutellum glabrous, impunctate, truncate and slightly narrower posteriorly. Legs pale except for darker patches from middle to apex of femora and tarsomeres 3-5. Femora weakly enlarged at middle. Legs short, metafemur extending to apical fourth of elytra. Venter mostly glabrous; impunctate except for metasternum, especially at side and along metepisternal margin which has scattered large, mostly separated, punctures of differing size, some of which bear a single seta. Prosternal process narrow, half as wide as base of femur, not expanded at apex; procoxal cavities open posteriorly by more than half the width of procoxa. Mesosternal process broad between coxae, over two-thirds as broad as mesocoxa. Metasternal sulcus pronounced, attaining anterior third of metasternum. Abdominal sternites successively narrowing; ventrite 5 longer than wide.

Discussion. Distenia puertoricensis is very similar in appearance to D. darlingtoni (Fig. 5e), the only other known species of Distenia in the Caribbean, but $D$. darlingtoni has rugose punctures on pronotum around central callus and between central callus and four lateral discal calli (Fig. 5d). In D. puertoricensis, the punctures are simple, mostly separate, not rugose around the middle callus and between the middle callus and the four peripheral discal calli (Fig. $5 b)$. In D. darlingtoni, the lateral pronotal tubercle is broad at base and broadly rounded at apex, not acute. In $D$. puertoricensis, the lateral pronotal tubercle is broad at base but greatly 
constricted at apex into a narrow nipple-like projection. In $D$. darlingtoni, presumably the sister species of $D$. puertoricensis, the metasternum, especially from lateral view, is smooth and lacks noticeable punctures or at most very finely punctate and is covered with very fine, translucent setae (Fig. 5c). In D. puertoricensis, the metasternum, especially from lateral view, has large but differently sized and separated punctures, some of which bear a single seta, but is otherwise glabrous (Fig. 5a). In D. darlingtoni, the last maxillary palpomere is narrowed and acute at apex, while in $D$. puertoricensis, the terminal palpomere is obliquely truncate. In $D$. darlingtoni, the elytra have a slight lateral constriction at middle. In D. puertoricensis, the elytra are slightly but steadily narrowed apically, without any noticeable constriction at middle.

Etymology. This species epithet is named after the island, Puerto Rico, where this species is widely distributed.

Types. Holotype, male, PUERTO RICO, Maricao For. Carr. 120, km 9-15, $18^{\circ} 08^{\prime} 45^{\prime \prime} \mathrm{N}$, $66^{\circ} 58^{\prime} 52^{\prime \prime} \mathrm{W}, 14$ June 2002, 850-950 m, beating vegetation, Steven W. Lingafelter (USNM). Paratypes: PUERTO RICO: 3 females, Maricao For. Carr. 120, km 12-15, $18^{\circ} 08^{\prime} 45^{\prime \prime} \mathrm{N}$, $66^{\circ} 58^{\prime} 52^{\prime \prime} \mathrm{W}$, 19 June 2003, 850-900 m, beating vegetation, Steven W. Lingafelter (USNM); 1 female, El Yunque Peak, Luquillo, 18 March 1936, L. F. Martorell coll. (USNM); 1 unsexed, Toro Negro For., 10 June 2002, Steven Lingafelter (RMPC); 1 female, El Yunque, Luquillo, 6-9 July 1969, Henry and Anne Howden (JAMC); 1 male, El Yunque, Luquillo, 10-16 July 1969, Henry and Anne Howden (JAMC); 1 female, Maricao, Hwy 120, km 10.2, 25 July 1979, Charles O'Brien (JAMC); 1 female, Caribbean National Forest, El Yunque, 02 June 1983, near USFWS aviary, 3,000', at light, E. LaRue (WIBF); 1 male, Maricao For. Carr. $120, \mathrm{~km} 9-15,18^{\circ} 08^{\prime} 45^{\prime \prime} \mathrm{N}, 66^{\circ} 58^{\prime} 52^{\prime \prime} \mathrm{W}, 14$ June $2002-850-950 \mathrm{~m}$, beating vegetation, Steven W. Lingafelter (DHPC).

DESCRIPTION OF LARVA OF PARANDRA TAVAKILIANI SANTOS-SILVA

Fig. $6 \mathrm{a}-\mathrm{d}$

Description. Cylindrical, prothoracic region and last three abdominal segments broader than segments between them. Mostly yellow-brown in color; clypeus, labrum, posterior prothoracic asperites darker brown; mandibles black. Sparsely pubescent with long, translucent to amber hairs on pleura and anterior of head. Head (Fig. 6a) short and broad, median suture short, connecting to broadly divergent margins of superior retractor muscle attachments. Labrum large, bluntly triangular, apical margin sparsely, short-setose, four longer sensory hairs arising from center. Clypeus glabrous, rectangular, short, about one half length of labrum. Epistoma not lobed over base of clypeus. Mandible very broad and massive at base; apex with acute projection leading to short, sub-apical, oblique cutting edge; mesal half with numerous closely-spaced longitudinal striations. Antenna (Fig. 6a, b, d) long, 4-segmented (plus small accessory antennomere); extending beyond anterior projection of mandible. Second antennomere shortest and weakly demarcated from first from dorsal view, but distinct from ventrolateral view. Fourth antennomere only slightly longer than second, but much smaller in diameter. Third antennomere slightly shorter than first. Maxillary palpus (Fig. 6d) 3segmented (a deep fold at top of stipes gives false appearance of another segment). Apex of galea even with distal margin of third palpomere. Labium (Fig. 6d) with 2-segmented palpus attached to a fleshy prementum base. Prementum distinctly demarcated by larger mentum which is demarcated from broad arcuate submentum that attaches to base of stipes of maxilla. Anterior margin of gula approximately equal to width of mentum. Hypostoma broad, 


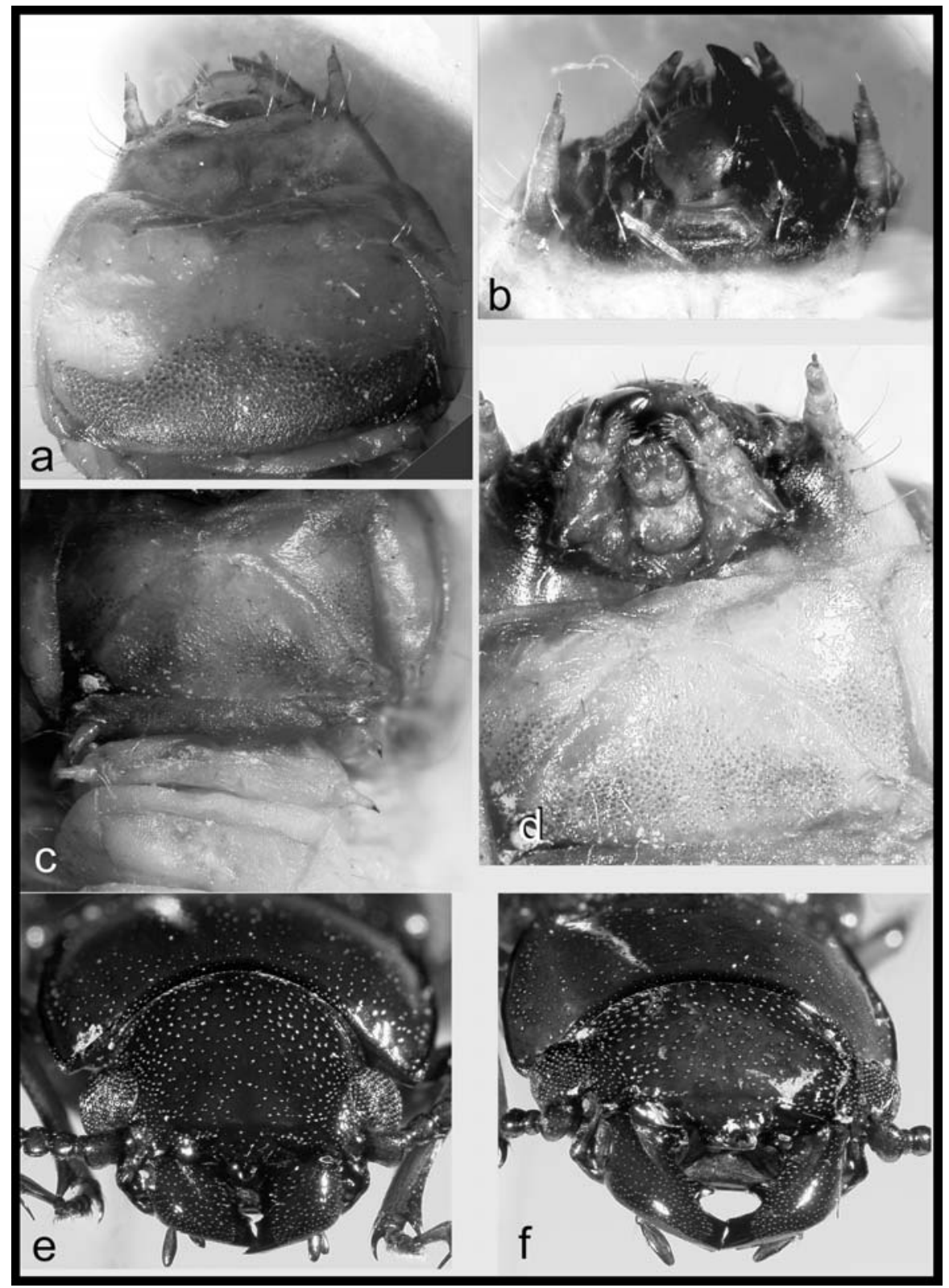

Fig. 6. Parandra tavakiliani Santos-Silva: a. dorsal head and prothorax of larva; b. closeup of dorsal mouthparts and antennae of larva; c. ventral thorax of larva; d. closeup of ventral mouthparts and prosternum of larva; e. head of adult female; f. head of adult male. 
Table 1. Summary of species collected in Puerto Rico in 2002-3. Abbreviations: $\mathrm{A}=$ Aguirre, $\mathrm{CA}=$ Cambalache, $\mathrm{CR}=$ Cabo Rojo, GJ $=$ Guajataca, $\mathrm{GN}=$ Guánica, $\mathrm{LDB}=$ Lago Dos Bocas, $\mathrm{LT}=$ Laguna Tortuguero, $\mathrm{M}=$ Maricao, $\mathrm{P}=$ Ponce, $\mathrm{RA}=$ Río Abajo, $\mathrm{S}=$ Susúa, $\mathrm{TN}=$ Toro Negro, $\mathrm{U}=$ Utuado, $\mathrm{Y}=\mathrm{El}$ Yunque. See Fig. 1 for map of localities.

\begin{tabular}{|c|c|c|c|}
\hline Cerambycidae taxon & \# spec. & Locality & Collection method \\
\hline \multicolumn{4}{|l|}{ Cerambycinae } \\
\hline $\begin{array}{l}\text { Achryson surinamum } \\
\text { (Linnaeus) }\end{array}$ & 1 & $\mathrm{P}$ & lights \\
\hline Chlorida festiva (Linnaeus) & 3 & $\mathrm{P}, \mathrm{U}, \mathrm{Y}$ & lights \\
\hline \multicolumn{4}{|l|}{ Curtomerus flavus } \\
\hline (Fabricius) & 3 & GJ, M & lights, beating \\
\hline Eburia portoricensis Fisher & 1 & $\mathrm{CR}$ & UV light \\
\hline \multicolumn{4}{|l|}{ Eburia quadrimaculata } \\
\hline \multicolumn{4}{|l|}{ Elaphidion n. sp (Ivie, in } \\
\hline \multicolumn{4}{|l|}{ Elaphidion irroratum } \\
\hline \multicolumn{4}{|l|}{ Lamproclytus elegans } \\
\hline \multicolumn{4}{|l|}{ Caribbomerus attenuatus } \\
\hline (Chevrolat) & 4 & $\mathrm{CR}, \mathrm{P}$ & beating, UV light \\
\hline $\begin{array}{l}\text { Methia necydalea } \\
\quad \text { (Fabricius) }\end{array}$ & 12 & $\mathrm{~A}, \mathrm{GN}, \mathrm{P}, \mathrm{Y}$ & $\begin{array}{l}\text { beating Leguminosae } \\
\text { trees, UV light }\end{array}$ \\
\hline $\begin{array}{l}\text { Neoclytus araneiformis } \\
\quad \text { (Olivier) }\end{array}$ & 8 & $\mathrm{CR}, \mathrm{LDB}, \mathrm{U}, \mathrm{Y}$ & $\begin{array}{l}\text { dead branches of } \\
\text { Prosopis juliflora }\end{array}$ \\
\hline $\begin{array}{l}\text { Plectromerus distinctus } \\
\quad \text { (Cameron) }\end{array}$ & 4 & GN, P & $\begin{array}{l}\text { beating Thouinia } \\
\text { portoricensis }\end{array}$ \\
\hline Plectromerus sp. & 1 & M & beating \\
\hline $\begin{array}{l}\text { Plinthocoelium } \\
\text { domingoensis (Fisher) } \\
\text { new tribe record for PR }\end{array}$ & 2 & M & $\begin{array}{l}\text { canopy flowers of } \\
\text { Turpenia paniculata }\end{array}$ \\
\hline Tilloclytus minutus Fisher & 5 & GN, M & beating \\
\hline $\begin{array}{l}\text { Pseudothonalmus woodleyi } \\
\text { Lingafelter, Micheli, and } \\
\text { Guerrero, new species, } \\
\text { new tribe record for PR }\end{array}$ & 1 & M & in flight \\
\hline \multicolumn{4}{|l|}{ Disteniinae } \\
\hline Distenia darlingtoni Fisher & 6 & $\mathrm{M}, \mathrm{TN}$ & beating foliage \\
\hline \multicolumn{4}{|l|}{ Lamiinae } \\
\hline \multicolumn{3}{|l|}{ Alcidion umbraticum } & beating \\
\hline \multicolumn{3}{|l|}{ Antilleptostylus nigricans } & beating \\
\hline $\begin{array}{l}\text { Ataxia spinipennis } \\
\quad \text { (Chevrolat) }\end{array}$ & 14 & $\mathrm{~A}, \mathrm{GN}, \mathrm{M}, \mathrm{Y}$ & beating dead branches \\
\hline \multicolumn{4}{|l|}{ Boricyrtinus nilseni } \\
\hline Micheli & 2 & $\mathrm{M}, \mathrm{Y}$ & beating \\
\hline
\end{tabular}


Table 1. Continued.

\begin{tabular}{|c|c|c|c|}
\hline Cerambycidae taxon & \# spec. & Locality & Collection method \\
\hline \multicolumn{4}{|l|}{ Cacostola leonensis } \\
\hline Dillon and Dillon & 2 & $\mathrm{~A}, \mathrm{M}$ & light, dead branches \\
\hline \multicolumn{4}{|l|}{ Cyrtinus oakleyi } \\
\hline \multicolumn{4}{|l|}{ Fisher first records for } \\
\hline PR since discovery & 2 & M & beating \\
\hline \multicolumn{4}{|l|}{ Decarthria boricua } \\
\hline Micheli & 1 & M & beating \\
\hline \multicolumn{4}{|l|}{ Desmiphora hirticollis } \\
\hline (Olivier) & 1 & M & light \\
\hline Ecyrus hirtipes Gahan & 5 & LT, M & lights \\
\hline \multicolumn{4}{|l|}{ Eugamandus flavipes } \\
\hline Fisher & 5 & Y & beating \\
\hline Eugamandus oakleyi Fisher & 5 & $\mathrm{M}, \mathrm{TN}, \mathrm{Y}$ & beating \\
\hline \multicolumn{4}{|l|}{ Eugamandus ricarti } \\
\hline Micheli & 4 & M & beating \\
\hline \multicolumn{4}{|l|}{ Lagocheirus araneiformis } \\
\hline guadeloupensis Dillon & 2 & $\mathrm{Y}$ & lights \\
\hline \multicolumn{4}{|l|}{ Leptostylopsis antillarum } \\
\hline (Fisher) & 12 & CA, M, RA, S & lights, beating \\
\hline \multicolumn{4}{|l|}{ Leptostylopsis argentatus } \\
\hline (Jacquelin du Val) & 1 & $S$ & beating \\
\hline \multicolumn{4}{|l|}{ Leptostylopsis gundlachi } \\
\hline (Fisher) & 5 & $\mathrm{M}, \mathrm{S}, \mathrm{U}$ & light, beating \\
\hline \multicolumn{4}{|l|}{ Leptostylopsis monin } \\
\hline $\begin{array}{l}\text { Micheli and Micheli } \\
\text { [In press] }\end{array}$ & 2 & M & beating \\
\hline \multicolumn{4}{|l|}{ Leptostylopsis yukiyu } \\
\hline \multicolumn{4}{|l|}{ Micheli and Micheli } \\
\hline \multicolumn{4}{|l|}{ Spalacopsis filum filum } \\
\hline (Klug) & 2 & M & beating vines \\
\hline $\begin{array}{l}\text { Styloleptus inflaticollis } \\
\text { (Chemsak) }\end{array}$ & 2 & $\mathrm{P}$ & $\begin{array}{l}\text { beating Avicennia germinans } \\
\text { (black mangrove) }\end{array}$ \\
\hline \multicolumn{4}{|l|}{ Styloleptus taino } \\
\hline \multicolumn{3}{|l|}{ Lingafelter and Micheli, } & beating branches \\
\hline \multicolumn{4}{|l|}{ Trypanidius nocturnus } \\
\hline Fisher & 2 & Y & lights \\
\hline \multicolumn{4}{|l|}{ Urgleptes puertoricensis } \\
\hline Gilmour & 1 & M & beating \\
\hline \multicolumn{4}{|l|}{ Urgleptes sandersoni } \\
\hline Gilmour & 46 & $\begin{array}{l}\text { CA, M, GJ, P, RA, } \\
\quad \text { S, TN, Y }\end{array}$ & beating \\
\hline \multicolumn{4}{|l|}{ Urgleptes borikensis } \\
\hline $\begin{array}{l}\text { Micheli and Micheli } \\
\text { [In press] }\end{array}$ & 10 & GN, M, Y & beating \\
\hline
\end{tabular}


Table 1. Continued.

\begin{tabular}{|c|c|c|c|}
\hline Cerambycidae taxon & \# spec. & Locality & Collection method \\
\hline \multicolumn{4}{|l|}{ Parandrinae } \\
\hline \multicolumn{4}{|l|}{ Parandra tavakiliani } \\
\hline Santos-Silva & 9 & $\mathrm{Y}$ & rotting tree, light \\
\hline \multicolumn{4}{|l|}{ Prioninae } \\
\hline \multicolumn{4}{|l|}{ Callipogon proletarium } \\
\hline Lameere & 1 & M & light \\
\hline Elateropsis julio & & & foliage of vine-covered \\
\hline $\begin{array}{l}\text { Lingafelter and Micheli, } \\
\text { new species, new genus } \\
\text { record for PR }\end{array}$ & 1 & $\mathrm{P}$ & Croton \\
\hline $\begin{array}{l}\text { Solenoptera bilineata } \\
\text { (Fabricius) }\end{array}$ & 3 & CA, M & in flight \\
\hline $\begin{array}{l}\text { Solenoptera michelii } \\
\text { (Chemsak) }\end{array}$ & 6 & GJ, RA, Y & in flight \\
\hline Solenoptera thomae & & & \\
\hline (Linnaeus) & 5 & $\mathrm{M}, \mathrm{P}$ & $\begin{array}{l}\text { in flight, on foliage } \\
\text { of Croton }\end{array}$ \\
\hline $\begin{array}{l}\text { Stenodontes exsertus } \\
\quad \text { (Olivier) }\end{array}$ & 5 & M & lights \\
\hline
\end{tabular}

distinctly delimited by suture. Prothorax prominent, greater in length than remainder of thorax plus first abdominal segment. Posterior half of pronotum distinctly asperate; the asperate region of a manta ray-like shape (Fig. 6a). Lateral margin with fold. Presternum separated distinctly from eusternum by broad, inverted $\mathrm{V}$-shaped sulcus, apex of which meets anterior margin and ends of which terminate at prothoracic legs (Fig. 6c). Asperites present throughout eusternum (except at margins) and posterior half of presternum. Prothoracic leg well developed, apparently 3-segmented (actually 4-segmented) with apical segment darkly pigmented. Prothoracic spiracle not evident. Mesothoracic spiracle oval and approximately 1.5 times length of remaining spiracles. Meso- and metathorax reduced and without conspicuous asperites, legs well developed, apparently 3-segmented (actually 4-segmented). No pair of oblique furrows from middle to base of legs; single tranverse furrow present (Fig. 6c). Abdomen with projecting, granulate ampullae on segments 1-7. Segments 8-9 broader and smoother than rest, with less distinctive ampullae and granulae. Abdominal segment 9 long and extended, without urogomphi or other modification.

Discussion. The adult of Parandra tavakiliani (Fig. 6e, f) was recently described (SantosSilva, 2002) and compared with $P$. cribrata Thomson, the only known species previously known from the Caribbean National Forest (El Yunque) (Wolcott, 1936, 1948). We discovered a population of adults of $P$. tavakiliani and one larva. The only Parandra species for which larvae have been described include: Parandra brunnea Fabricius, $P$. punctata White, $P$. glabra (Degeer), P. gabonica Thomson, $P$. caspia Ménétries, and P. expectata Lameere (Costa et al., 1988; Zajciw, 1974; Craighead, 1915; Duffy, 1957, 1960; Svacha and Danilevsky, 1987). Parandra tavakiliani Santos-Silva is distinctive in its manta ray-like pattern of asperites on the pronotum, the inverted V-shaped sulcus separating the eusternum 
from presternum and the pattern of asperites therein, the well developed, obviously 4segmented antennae, and the transverse (neither oblique nor paired) meso- and metasternal sulcus between the legs.

Material examined. PUERTO RICO: 1 larva and 8 adults in large, decomposing fallen tree in the northeastern part of El Yunque (USNM, specimen preserved in alcohol).

\section{ACKNOWLEDGMENTS}

We are grateful to Julio Micheli for hosting us and assisting us in many ways during our trip and for providing valuable insight on taxonomy of Puerto Rican Cerambycidae. We also thank Mona Micheli, Juan L. R. Ricart, Nilsen Micheli, Manuel Micheli, and Diana Micheli for their help and companionship. Norman Woodley participated fully in the expedition and collected two of the new species. Kelvin Guerrero generously provided the generic description for the heteropsine and discussed issues of systematics of this group of longhorns. Michael Ivie corrected several errors and provided taxonomical knowledge and specimen data from his collection. Partial funding for this trip was secured by Charlie Mitter through the Department of Entomology, University of Maryland, and by an NSF Graduate Research Fellowship awarded to CJM. E. Richard Hoebeke provided valuable logistical advice prior to the trip. Carolyn Krupp (USDA Forest Service, Caribbean National Forest) facilitated the collecting permit for the Caribbean National Forest, El Yunque. Judith Ruiz and Marilyn Colón (Oficina de Permisos, San Juan) helped us with permits for all the state forests in Puerto Rico. Ivette Barahona assisted us with accommodations at El Verde. We thank Julio Micheli, Allen Norrbom, Stuart McKamey, and an anonymous person for providing helpful reviews of the manuscript.

\section{LITERATURE CITED}

Blackwelder, R. E. 1946. Checklist of the coleopterous insects of Mexico, Central America, the West Indies and South America. Part 4. Bulletin of the United States National Museum 185: 551-763.

Cazier, M. A. and L. Lacey. 1952. The Cerambycidae of the Bahama Islands, British West Indies (Coleoptera). American Museum Novitates 1588: 1-55.

Chemsak, J. A. 1979. New species of Neotropical Prioninae. Coleopterists Bulletin 33(1): 125-128.

Chevrolat, L. A. 1858. Description de Coléoptères de la partie méridionale de l'Ile de Cuba. Revue Magasin de Zoologie 2(10): 209-211.

Costa, C., S. A. Vanin and S. A. Casari-Chen. 1988. Larvas de Coleoptera do Brasil. Museu de Zoologia, Universidade de São Paulo, São Paulo: 282 pp. +165 plates.

Craighead, F. C. 1915. Contributions toward a classification and biology of the North American Cerambycidae. Larvae of the Prioninae. United States Department of Agriculture, Report No. 107: 3-24, plates I-VIII.

Dillon, L. S. 1956. The Nearctic components of the tribe Acanthocinini (Coleoptera: Cerambycidae). Part 1. Annals of the Entomological Society of America 49(2): 134-167.

Dillon, L. S. and E. S. Dillon. 1946. The tribe Onciderini. Part 2. Reading Public Museum and Art Gallery Scientific Publications 6: 189-413 + 17 plates.

Duffy, E. A. J. 1957. A monograph of the immature stages of African timber beetles (Cerambycidae). British Museum (Natural History), Norwich: 338 pp. +10 plates.

Duffy, E. A. J. 1960. A monograph of the immature stages of Neotropical timber beetles (Cerambycidae). British Museum (Natural History), Norwich: 327 pp. +13 plates.

Ewel, J. J. and J. L. Whitmore. 1973. The ecological life zones of Puerto Rico and the U. S. Virgin Islands. U. S. Forest Service, Institute of Tropical Forestry, Rio Piedras, Puerto Rico. Research Paper ITF-18: 72 pp. + map.

Fisher, W. S. 1925. New West Indian Cerambycidae (Coleoptera). Subfamily Lamiinae. American Museum Novitates (174): 1-16. 
Fisher, W. S. 1926. Descriptions of New West Indian longicorn beetles of the subfamily Lamiinae. Proceedings of the United States National Museum 68(22): 1-40.

Fisher, W. S. 1932. New West Indian cerambycid beetles. Proceedings of the United States National Museum 80(22): 1-93.

Fisher, W. S. 1935. New cerambycid beetles from Puerto Rico. The Journal of Agriculture of the University of Puerto Rico 19(2): 51-63.

Fisher, W. S. 1942. New West Indian cerambycid beetles III. Torreia 10: 1-43.

Fisher, W. S. 1947. New West Indian cerambycid beetles IV. Memorias de la Sociedad Cubana de Historia Natural 19: 29-41.

Gahan, C. J. 1895. On the longicorn Coleoptera of the West Indian Islands. Transactions of the Entomological Society of London 1895: 79-140.

Galileo, M. H. M. and U. R. Martins. 1994. Revisão da tribo Solenopterini (Coleoptera, Cerambycidae, Prioninae). Part IV. Gênero Elateropsis Chevrolat, 1862 e distribuição geográfica da tribu. Revista brasileira de Entomologia 38(1): 109-153.

Gilmour, E. F. 1963. On the Neotropical Acanthocinini (Col., Cerambycidae, Lamiinae) some Caribbean genera and species. Studies on the Fauna of Curaçao and other Caribbean islands (76): 57-96 + 4 plates.

Guerrero, K. A. 2001. A revision and phylogenetic analyisis of Trichrous Chevrolat 1858, and a review of Plectrocerum Dejean 1835 (Coleoptera: Cerambycidae: Elaphidiini). Master of Science thesis, Montana State University, Bozeman. [unpublished]

Guerrero, K. A. and M. A. Ivie In preparation. A revision and phylogenetic analysis of Trichrous Chevrolat (Coleoptera: Cerambycidae: Elaphidiini).

Gundlach, J. 1894. Apuntes para la fauna Puerto-Riqueña. Anales de la Sociedad Española de Historia Natural 22(8): 259-344.

Ivie, M. A. 1985. Nomenclatorial notes on West Indian Elaphidiini (Coleoptera Cerambycidae). PanPacific Entomologist 61(4): 303-314.

Ivie, M. A. and M. L. Schwengel-Regala. In preparation. The Elaphidion Audinet-Serville of the Puerto Rican Bank: New species, distributions, taxonomic corrections, and a key to species (Coleoptera: Cerambycidae: Elaphidiini).

Leng, C. W. and A. J. Mutchler. 1914. A preliminary list of the Coleoptera of the West Indies as recorded to January 1, 1914. Bulletin of the American Museum of Natural History 33: 391-493.

Micheli, J. A. 1978. Ten new insect records from Puerto Rico (Coleoptera). The Journal of Agriculture of the University of Puerto Rico 67(3): 301-303.

Micheli, J. A. 2003. New longhorn beetles from Puerto Rico (West Indies) (Coleoptera: Cerambycidae). Coleopterists Bulletin 57(2): 191-204.

Micheli, J. A. and F. T. Hovore. 2003. New synonymies and distributional records for Caribbean Cerambycidae (Coleoptera). Coleopterists Bulletin 57(1): 1-4.

Micheli, J. A. and C. J. Micheli. 2004. Five new Puerto Rican longhorn beetles and other notes on West Indian Acanthocinini (Coleoptera: Cerambycidae: Lamiinae). Journal of the New York Entomological Society (in press).

Ramos, J. A. 1946. The insects of Mona Island (West Indies). The Journal of Agriculture of the University of Puerto Rico 30(1): 1-74 + 2 plates.

Santos-Silva, A. 2002. Notas e descrições em Parandrini (Coleoptera, Cerambycidae, Parandrinae). Iheringia, Séries Zoología 92(2): 29-52.

Stahl, A. 1882. Fauna de Puerto-Rico: Insecta. San Juan: 82-102, 169-213.

Svácha, P. and M. L. Danilevsky. 1987. Cerambycoid larvae of Europe and Soviet Union (Coleoptera, Cerambycoidea). Part 1. Acta Universitatis Carolinae-Biologica 30(1-2): 1-176.

Tyson, W. H. 1973. The Spalacopsis of the West Indies and America north of Mexico (Coleoptera: Cerambycidae). Coleopterists Bulletin 27(3): 117-137.

White, A. 1853. Catalogue of the coleopterous insects in the collection of the British Museum. Longicornia 1, London (7): 1-174. 
Wolcott, G. N. 1924. "Insectae Portoricensis". A preliminary annotated check-list of the insects of Porto Rico, with descriptions of some new species. Journal of the Department of Agriculture of Porto Rico 7(1): 1-313.

Wolcott, G. N. 1936. "Insectae Borinquenses". A revised annotated check-list of the insects of Puerto Rico. The Journal of Agriculture of the University of Puerto Rico 20(1): 1-600.

Wolcott, G. N. 1948. The insects of Puerto Rico. Journal of the Department of Agriculture of Porto Rico 32(2): 225-416.

Zajciw, D. 1974. Descriptions of larva and pupa Parandra (Archandra) expectata Lam. 1902 (Coleoptera, Cerambycidae, Parandrinae). Revista Brasileira de Biologia 34(1): 101-104.

Zayas, F. 1957. Revisión de los longicornios priónidos de Cuba (Coleópteros, Cerambycidae). Memorias de la Sociedad Cubana de Historia Natural 23(2): 149-174 + 7 plates.

Zayas, F. 1975. Revisión de la familia Cerambycidae (Coleoptera, Phytophagoidea). La Habana, Academia de Ciencias de Cuba: 443 pp.

Received 3 July 2003; accepted 26 February 2004. 